doses, with the result that thyroid medication has been abandoned as useless in certain cases because the quantity given was quite inadequate. Patients who require large doses do not necessarily present the classical appearance and all the symptoms of myxodema, although signs of hypothyroidism are present in some degree. The tolerance of every case must be determined individually by observing the weight, pulserate, temperature, and subjective symptoms; unless this is done, there is as much likelihood of under-as of over-dosage.

As examples of high thyroid tolerance I may refer to two cases. One is a lady with Raynaud's disease and the peripheral form of scleroderma involving the hands, feet, and lower parts of the forearms and legs. The urine contained a large quantity of indican, and $\mathrm{X}$ ray examination of the alimentary tract showed a distended dropped cæcum, in which there was considerable stasis. No other source of toxæmia was discovered. An abnormal strain of $B$. coli was isolated from the fæces, which was agglutinated by the patient's serum in a dilution of $1 / 200$. Subcutaneous fat was in excess in the abdominal wall and on the thighs and legs, the temperature was subnormal, and the pulse-rate rather slow. Small doses of thyroid had been given over considerable periods without apparent benefit. She is now taking $20 \mathrm{gr}$. of thyroid gland (Burroughs and Wellcome's "tabloids" and Armour's tablets have been employed) per diem; it was not until $17 \mathrm{gr}$. a day were being given that the temperature reached the normal line. There is very great improvement in her general health, the Raynaud symptoms are much less evident, and the skin of the sclerodermatous areas is becoming soft again. The pulse-rate remains between 70 and 80 .

The other case, a Dutch girl, came to me for almost complete alopecia of the scalp of severa! years' duration. She is mentally very alert, but signs of hypothyroidism are present. For several weeks she took $10 \mathrm{gr}$. of thyroid gland (i.e., two of B. W. and Co.'s 5 gr. tabloids) per diem without any untoward symptoms, but is now having $7 \mathrm{gr}$. $\Lambda$ s a result of this treatment her weight has been reduced from 11 to 10 stone, her pulse-rate has risen from 65 to 72 , and hair is now growing freely over the whole scalp. On $7 \mathrm{gr}$. per diem her weight and pulse-rate remain constant.

The tolerance of the first case must, I think, be quite exceptional. One point, often apparently overlooked by enthusiastic ductless-gland therapists, is that in giving thyroid to those who during early life or middle-age have developed hypothyroidism, we are treating a secondary symptom and not a primary cause. We are still very ignorant of the possible factors involved in the development of thyroid insufficiency.-I am, Sir, yours faithfully,

Deronshire-place, w.., Feb. 25th, 1922. H. W. BARBER.

\section{THE ERLANGEN METHOD OF X RAY TREATMENT.}

To the Editor of The LANCET.

SIR,- - In this treatment, in which attempts are made to give a lethal dose to the cancer cell, it appears that sufficient attention has not been paid to our knowledge of the varying susceptibility of malignant tumours. Clinical experience shows that this must be great. From the experimental standpoint, H.C. Wood, for instance (Journal of Cancer Research. April, 1921, p. 177), has shown that for carcinoma this may vary from two to eight erythema doses. It must therefore be misleading to speak of a destructive carcinoma dose as being 90-110 per cent. Even tumours of similar microscopic appearances vary widely in susceptibility.

In the comparison of $X$ rays with radium in the treatment of deep-seated tumours Dr. R. Morton, in his paper in the last issue of THE LANCET, did not draw attention to a very great advantage that radium has over $X$ rays when it is buried among the tumour cells, for in this way all the cells of a tumour can be given a lethal dose with a minimal exposure of the surrounding healthy tissue. It is true that in the immediate neighbourhood of the radium the cancer cells will receive more than the lethal dose, and sufficient perhaps to produce a sloughing of the centre of the tumour. But this disadvantage is not to be compared with the disadvantage of, or even danger from, the profound constitutional changes, annemia, \&c., which follow $X$ ray treatment by the Erlangen methods, and which are due to the very large doses which the normal tissues of the patient receive.

I am, Sir, yours faithfully, J. C. Mottran.

The Radium Institute, Feb. 28th, 1922.

\section{The Sertices.}

ROYAL ARMY MEDICAL CORPS.

Maj.-Gen. Sir G. D. Bourke, ret. pay, is appointed Col. Comdt., vice Surg.-Gen. (ranking as Maj.-Gen.) Sir F. W. Trevor, ret. pay.

Lt.-Col. E. W. W. Cochrane retires on ret. pay and is granted the rank of $\mathrm{Col}$.

Maj. R. J. Cahill relinquishes the temp. rank of Lt.-Col,

Capt. E. F. W. Mackenzie relinquishes the temp. rank of Maj. on ceasing to be spec. empld.

Temp. Capt. E. C. Lindsey relinquishes his commn. and retains the rank of capt.

MILITIA.

The undermentioned relinquish their commns. : Lt.-Col. J. Clerke (retains the rank of Lt.-Col.); Maj. R. J. Stirling (retains the rank of Maj.).

Capt. K. B. MacGlashan to be Maj.

INDIAN MEDICAL SERVICE.

Col. Bhola Nauth is appointed Hon. Physician to the King, vice Maj.-Gen. P. Carr-White (ret.).

The undermentioned are appointed Hon. Surgeons to the King: Col. J. K. Close, vice Hon. Col. Sir W. R. Hooper (decd ); and Col. W. G. Pridmore, vice Surg.-MIaj.-Gen. P. S. Turnbull (decd.).

\section{(10biturtr.}

CHARLES WRAY, F.R.C.S. ENG.

Mr. Charles Wray, who died in a London nursing home on Feb. 13th at the age of 63 , was ophthalmic surgeon to the Croydon General Hospital, infirmary, and council school. A Yorkshireman by birth, he received his medical education at the London Hospital. qualifying M.R.C.S. in 1881; his work was purely ophthalmic, and his early appointments were at the Royal London Ophthalmic Hospital, the Royal Eye Hospital, and the Western Ophthalmic Hospital. He became F.R.C.S. in 1886, and in 1887 was responsible for the opening of the first special department at the Croydon General Hospital, where he continued to work almost to the end of his life. So highly valued were his services that upon the completion of his regulation 25 years' tenure of the post of ophthalmic surgeon the hospital committee took the exceptional step of requesting him to retain his position, which he consented to do. A colleague writes :-

" He was a most charming man to work with, ever ready to help in any difficult question of diagnosis or treatment and to give the benefit of his mature judgment and ripe experience. He was a skilful operator.... a man of most generous disposition and great originality, who retained an unbounded enthusiasm for his work until the last."

Wray's consideration for his patients, together with his unusual power of organisation, explained the popularity of his department and the large number of attendances with which he was able to deal. He was a frequent contributor to our columns and to the ophthalmological journals, his contributions covering a wide area of knowledge, although his special and particular interests were conical cornea and bony tumours of the orbit. For many years he was a leading menuber of the Croydon Medical Society. He is survived by his widow. 